\title{
Standardization of distance and angulation of light curing unit tip using distometer
}

\begin{abstract}
The purpose of this study was to investigate the light intensity of selected light curing unit with varying distance and angulation of the light curing tip and lightmeter.

Four types of light units; Spectrum 800 (Dentsply), Coltulux 3 (Coltene), Elipar FreeLight 2 (3M Espe) and Starlight Pro (Mectron) were evaluated for light intensity at various distance between the light curing tip and the lightometer Cure Rite Denstply $(0,1,3,5$, 10 and $15 \mathrm{~mm}$ ). The light curing units were angulated at 45 degrees, 60 degrees and 90 degrees at a standardized $5 \mathrm{~mm}$ distance.

The intensity of light curing is affected by the distance between the light curing tip and the lightmeter. However, the decrease in light intensity of the light curing unit was found not to obey the inverse square law for the distances 0 to $15 \mathrm{Mm}$.

The study found that there was no significant difference between 45 degrees and 600 angulation between the light curing tip and the lightmeter. However, the decrease in light intensity is significant when compared to the light tip is placed perpendicular (90 degrees) to the aperture of the light meter.
\end{abstract}

Authors:

Radzi, Z. ; Abu Kasim, N. H. ; Yahya, N. A. ; Abu Osman, N. A. ; Kassim, N. L.

Book: $\quad 3 r d$ Kuala Lumpur International Conference on Biomedical Engineering 2006

Year: $\quad 2006$

Pages: $141-143$

Publication date: $\quad$ Dec 2006

\section{Keywords :}

distance; angulation; light curing unit; light intensity; composite resin COMPOSITE RESIN 


\section{Please cite as :}

Radzi, Z., N. H. Abu Kasim, et al. (2007). Standardization of distance and angulation of light curing unit tip using distometer. 3rd Kuala Lumpur International Conference on Biomedical Engineering 2006. F. Ibrahim, N. A. A. Osman, J. Usman and N. A. Kadri. Kuala Lumpur, SPRINGER, 233 SPRING STREET, NEW YORK, NY 10013, UNITED STATES. 15: 141-143.

\section{URL :}

- http://www.springerlink.com/content/g5457009364q656w/

- $\quad$ http://books.google.com.my/books?id=sdG1hN 4TYC\&pg=PA357\&lpg=PA357\&dq=Standardization+of+distance+and+ang ulation+of+light+curing+unit+tip+using+distometer\&source=bl\&ots=eL04WIK6eS \&sig=oVCigyuFIIF2ICrPi iuRDegeyQ\&hl=en\&ei=QmfhTuyqlliJrQfMsIH9AQ\&sa= X\&oi=book result\&ct=result\&resnum $=3 \&$ sqi $=2 \& v e d=0$ CEAQ6AEwAg\#v=onepag e\&q=Standardization\%20 of\%20distance\%20and\%20angulation\%20of\%20light\% 20curing\%20unit\%20tip\%20using\%20distometer\&f=false 